UDC 376-056.2/.3(510)

DOI https://doi.org/10.31470/2415-3729-2020-12-214-228

\title{
Organization of Inclusive Education in China
}

\section{Zeng Guanghai}

Postgraduate of the Department of Pedagogics, H.S. Skovoroda Kharkiv National Pedagogical University,

$\triangle 29$, Alchevskykh Str., Kharkiv, Ukraine, 61002

E-mail:937732545@qq.com

ORCID: http://orcid.org/0000-0003-1262-1512

Дата надходження статті: 28 вересня 2020 р. Стаття прийнята до друку: 22 листопада 2020 р.

\section{Організація інклюзивної освіти в КНР}

\section{Цзен Гуанхай}

аспірант кафедри педагогіки,

Харківський національний педагогічний університеті імені

Г.С. Сковороди,

вул. Алчевських, 29, м. Харків, Україна

Date of receipt of the article: September 28, 2020

Article accepted for publication: November 22, 2020

\section{Abstract}

The article is devoted to the problem of organizing inclusive education in China, the ways of mastering the education by students with special educational needs, developing their personal qualities, ability to social interaction, achieving equality in education and social justice. Since the proclamation of the Salamanca Declaration in 1994, many countries around the world, including China, have been moving towards inclusive education. The article examines the history and directions of inclusive 
education in China. The author examines the experience of teachers in the organization of inclusive education, barriers and problems of development and implementation of Chinese inclusive education. The purpose of the article is to determine the main prerequisites for the organization of inclusive education in China. The main methods used in this study are the analysis and synthesis of scientific literature and open government regulations in the field of inclusive education in China.

The results. The author found that despite all the measures taken by the Chinese government, inclusive education still lags behind European countries, where children with disabilities are full members of society and are not perceived by others as "others". It is determined that special attention is paid to the study of inclusive education and the development of plans for the development of inclusive education. Given the need for inclusive education, which is a priority, inclusive education institutes and resource centers are being set up across the country. Conclusions. The main preconditions for the organization of inclusive education in China include the following: the inclusion of all children with different educational needs in traditional general secondary education institutions, which they could attend if they did not have a disability; the lack of "sorting" and selection of children, learning in mixed classes; the distribution of children with physical and mental characteristics by classes, according to their age; the situationally conditioned bulk interaction and coordination of resources and teaching methods; the use of decentralized learning models.

Key words: inclusive education, China, educational process, children with special educational needs, social justice.

\section{References}

1. Central Committee of the Communist Party of China. (2010). Outline of the National Plan for Medium and Long-Term Education Reform and Development (2010-2020). Beijing: Central Committee of the Communist Party of China. 
2. Chen, Y.Y. (1996). Making special education compulsory and inclusive in China. Cambridge Journal of Education, 26(1), 47-59.

3. Chen, Y.Y. (1997). The research on effect evaluation of learning in the regular classroom of the disabled children. Chinese Journal of Special Education, 3, 45-48.

4. Deng, M., \& Harris, K. (2008). Meeting the needs of students with disabilities in general education in China. Teacher Education and Special Education, 31(3), 195-207.

5. Deng, M., \& Poon-McBrayer, K.. (2004). Inclusive education in China: Conceptualization and realization. Asia Pacific Journal of Education, 24(2), 143-156.

6. Deng, M., \& Zhu, Z. (2007). The Chinese "learning in a regular classroom" and Western inclusive education: A comparison and exploration. Chinese Education and Society, 40(4), 21-32.

7. Hu, X.Y., Wang, M., \& Xiao, F. (2012). Family quality of life of Chinese families of children with intellectual disabilities. Journal of Intellectual Disability Research, 56(1), 30-44.

8. McCabe, H. (2003). The beginnings of inclusion in the People's Republic of China. Research and Practice for Persons with Severe Disabilities, 28(1), 16-22.

9. Ministry of Education of the People's Republic of China. (2014). Special Education Improvement Act. Beijing: Author.

10. Ministry of Education of the People's Republic of China. (2016a). 2015 National Education Statistics. Beijing: Author.

11. National Bureau of Statistics of China. (2007). 2006 Disability National Census. Beijing: Author.

12. National People's Congress. (1986). Compulsory Education Law. Beijing: Author.

13. National People's Congress. (2006). Compulsory Education Law. Beijing: Author.

14. National People's Congress. (2008). Law on the Protection of Disabled Persons. Beijing: Author. 
15. Wang, P., \& Michaels, C. A. (2010). Chinese families of children with severe disabilities: Family needs and available support. Research and Practice for Persons With Severe Disabilities, 34(2), 21-32.

16. Wu, S.L., \& Wang, Y.L. (2016). Initiatives and practices of home schooling in inclusive education era. Journal of Modern Special Education, 7, 9-11.

\section{Вступ}

У сучасному світі інклюзивний освітній процес все більше актуалізується і передбачає організацію навчальної діяльності, що задовольняє освітні потреби кожної дитини, незалежно від фізичного і психічного їі розвитку. Важливим питанням освіти дітей з особливими освітніми потребами $\epsilon$ розширення можливостей соціалізації учнів, необхідні для включення кожної дитини в суспільство, даючи рівні права на набуття освітніх компетентностей всіх дітей. Для реалізації цих прав потрібні не тільки зміни в структурі та роботи школи, а також зміни в поглядах вихователів закладів дошкільноої освіти, вчителів закладів загальної та спеціальної освіти, які звикли розглядати свою роботу як навчання тільки певних груп дітей та зміни ставлення суспільства до дітей з особливими освітніми потребами в цілому.

Закон про обов'язкову освіту, прийнятий у 1986 р., передбачав, що всі діти починають з шестирічного віку, отримують 9-річну безкоштовну державну освіту незалежно від їхньої «статі, раси, етнічної приналежності, соціальноекономічний статусу родини або релігійних вірувань» (National People's Congress, 1986, p. 1).

Історично склалося, що дітям з особливими освітніми потребами в Китаї не були надані освітні права (Chen, 1996; McCabe, 2003). Навчання дітей з особливими освітніми потребами було можливим лише через спеціальні школи (наприклад, школи для дітей 3 порушенням зору або 
порушенням слуху тощо). Навіть для цих дітей спеціалізовані школи не завжди були доступними, особливо в сільській місцевості, де не було можливості школам дозволити собі такі програми. Визнаючи обмеженість спеціалізованих шкіл, за ініціативи Міністерства освіти КНР було визначено сприяти інклюзіі, а скоріше надавати настанови для звернення до освітніх послуг для дітейінвалідів з обмеженим доступом до спеціалізованих шкіл (Chen, 1996, 1997; McCabe, 2003).

Хоча початкова ідея щодо навчання дітей з особливими освітніми потребами не стосувалася безпосередньо організації інклюзивної освіти в китайських школах, іiі подальший розвиток був значним під впливом світових тенденцій наприкінці 1980-х (Deng \& Harris, 2008; Deng \& Poon-McBrayer, 2004). Повторне затвердження навчальних програм для організації інклюзивної освіти для дітей 3 особливими освітніми потребами відбулося у 2006 p. (National People's Congress, 2006) та на підставі Закону про захист інвалідів (National People's Congress, 2008), які мали змогу навчатися в звичайних школах. Діти 3 легкими / середніми вадами розвитку (наприклад, порушення чутливості, емоційні (поведінкові розлади) були первинними для того, аби уможливити організацію освітнього простору для дітей з особливими потребами. Доступ до загальної освіти та участь у ній продовжували змінюватися залежно від географічного району, інвалідності дитини, ресурсів, наявності професіоналів та інших чинників (Hu, Wang, \& Xiao, 2012; Wang \& Michaels, 2010).

Слід зазначити, що у сільських районах Китаю проживає понад $80 \%$ дітей 3 особливими освітніми потребами, наприклад, обов'язкову освіту не здобувають навіть ті діти, які не мають інвалідності (Deng \& Harris, 2008; Deng \& Zhu, 2007). Національний перепис населення Китаю (National Bureau of Statistics of China, 2007) надав підстави стверджувати, що лише $63 \%$ дітей 3 обмеженими 
можливостями здобували обов'язкову освіту. 3 цих 63\% лише 54\% навчалися в закладах загальної середньої освіти (Ministry of Education of the People's Republic of China, 2016a).

Метою статmі є визначення основних передумов організації інклюзивної освіти в Китаї.

\section{Методи дослідження}

Серед використаних методів дослідження визначальними були такі: аналіз та узагальнення науковометодичних джерел, державних документів 3 теми дослідження задля теоретичного обгрунтування висвітлюваної проблеми, синтез отриманих даних щодо визначення передумов організації інклюзивної освіти в Китаї.

\section{Результати та їх обговорення}

В процесі проведеного аналізу встановлено, що інклюзивна освіта в Китай прийшло з Заходу і виникла в результаті інтеграції культур. Цей вид освіти укорінився в унікальну культуру Китаю, адаптуючись до традиційної освіти, і поступово в Китаї зародилася теорія інклюзивної освіти (Armstrong \& Spandagou, 2011).

Традиційній культурі Китаю властиво обережне ставлення до всього, що може порушити наявну стабільність. Тому будь-яке відхилення від звичного сприймається суспільством як спроба дестабілізації. У традиційній картині світу Китаю, простір і час є єдиним цілим, яке розділене на «наше» і «чуже». «Наше»- це територія заселена людьми, «чужа» - духами, демонами і нечистю.

Упродовж багатьох століть люди 3 обмеженими можливостями не тільки не мали можливості здобувати освіту, а й жили в повній ізоляції від суспільства. Таким чином, всі категорії «чужих» виводилися за межі «свого простору» i допустимий формат спілкування 3 такими людьми традиційно припускав повну ізоляцію.

Ще в тексті Стародавнього Китаю «Го юй» («Речі царств») IV-III ст. до н.е. в розділі «Речі царства Чжоу», де 
ведеться обговорення способів підтримки стабільності в Піднебесній, згадується про сліпих. У давньо-китайській мові терміни «музикант» і «сліпий» позначалися одним і тим же ієрогліфом «гу», що вказує нам, що ці люди були особливими, тому що вважалося, що музика йде до нас 3 Космосу.

Однак, внаслідок розвитку інклюзивної освіти за кордоном і потребами розвитку освіти в Китаї, з кінця 1980х р. китайський уряд став упроваджувати практику спільного навчання дітей $\mathrm{i}$ дітей 3 обмеженими можливостями у звичайних школах. Суть даного процесу полягала в тому, щоб привести особливих дітей в звичайні школи і звичайні класи, де навчання відбувалося б спільно з іншими учнями.

Одним 3 важливих заходів 3 розвитку спеціальної освіти було створення відповідних документів в законодавчій базі. Така практика була визначена як одна з основних форм інклюзивної освіти. Беручи до уваги той чинник, що з часу утворення КНР (1949), коли на момент проголошення іii незалежності понад 80\% населення було неписьменним, а економіка Китаю перебувала в занепаді, в найкоротші терміни країна була охоплена обов'язковою дев'ятирічною освітою.

Після того було введено обов'язкову освіту для дітей 3 обмеженими можливостями та досягнуті позитивні результати в галузі інклюзивної освіти.

Широке поширення i розвиток інклюзивна освіта отримала після прийняття в 1994 р. в Іспанії Саламанської декларації на Всесвітній конференції щодо життєдіяльності осіб з особливими потребами, проведеної ЮНЕСКО і закріпила принципи інклюзивного навчання.

Вищезазначене слугувало початком вивчення i впровадження методик роботи з особливими дітьми на офіційному рівні і отримало підтримку уряду щодо реалізації даної програми. 
Нині права на навчання осіб 3 обмеженими можливостями регулюються «Законом про охорону інвалідів КНР», «Положенням про освіту інвалідів», Конституцією КНР, «Законом про освіту КНР», «Законом про обов’язкову освіту КНР».

Зміст провідних досліджень та урядових документів надають підстави характеризувати організацію інклюзивної освіти в Китаї:

1. Терміни початку шкільного навчання сліпих, німих, розумово відсталих дітей можуть бути розширені відповідно до їхніх індивідуальних потреб.

2. Способи i форми навчання повинні бути гнучкими i різноманітними: окрім установи спеціалізованих шкіл, можливе створення при традиційних початкових або базових школах спеціальних груп для дітей 3 обмеженими можливостями, в яких навчатимуться діти-інваліди.

Однак вищезазначене не повинно перешкоджати відвідуванню початкової і базової школи звичайним учням.

Важливим для нашого дослідження є той чинник, що Державний комітет з освіти в Китаї в 1994 р. уточнив правила проведення спільного навчання:

1. Діти з обмеженими можливостями, які беруть участь в програмах спільного навчання, повинні відвідувати школу за місцем проживання (поблизу).

2. Вік вступу до школи дітей 3 обмеженими можливостями і звичайних дітей повинен бути однаковий. В особливих випадках можливе регулювання.

3. Кількість дітей 3 обмеженими можливостями у звичайних школах в класах зі спільним навчанням повинно бути 1-2 учні, але не більше ніж 3.

4. Звичайні школи повинні, відповідно до законодавства, надавати освітні послуги дітям 3 обмеженими можливостями.

5. Школи не мають права відмовляти в освітніх послугах дітям інвалідам. 
Після прийняття в 1994 р. положення «Про впровадження методів інтегрованого навчання в роботу з розвитку дітей з обмеженими можливостями» практика інтегрованого навчання отримала поширення по всьому Китаю і стала новим етапом проведення реформ в освіті. Даний метод повинен був сприяти зняттю дефіциту освітніх можливостей для дітей з обмеженими можливостями за допомогою інтегрування особливих дітей в звичайний освітній процес і як наслідок зростання толерантності по відношенню до інвалідів і подальше інтегрування їх в соціальне життя.

Цінними, 3 огляду на досліджувану проблему, $є$ рекомендації щодо підтримка студентів 3 обмеженими можливостями на різних рівнях, забезпечення підготовки всіх студентів як до академічної, так і до професійні галузі та інтеграція освітньої та медичної підтримки (Ministry of Education of the People's Republic of China, 2014). Завдяки цим зусиллям політики не лише посилили акцент на рівності освіти та справедливості, але також створила підгрунтя для інклюзивної освіти.

Закон полягає у всебічній пропаганді інклюзивної освіти, аби усі студенти з обмеженими можливостями отримували відповідну освіту» (Ministry of Education of the People's Republic of China, 2014, p. 1).

Слід зазначити, що окрім позитивних моментів впровадження інклюзивної освіти в навчальні заклади Китаю, існують і певні бар'єри. Один із них полягає в тому, що студенти, які не мають доступу до спеціалізованих програм, досить часто проходять домашнє навчання в родині (Wu \& Wang, 2016).

Ще одним бар'єром є створення більш відокремлених спеціалізованих шкіл у всіх регіонах Китаю. Це розширення може бути частково віднесено до політичного документа, «Конспект Національного плану на середньострокову та довгострокову перспективу щодо розвитку освіти» (Central 
Committee of the Communist Party of China, 2010), зазначивши, що до 2020 р. міста та провінції з населенням 300000 або більше повинні мати принаймні одну спеціальну шкільну освіту.

Отже, підсумовуючи, зазначимо, що Китай за останні два-три десятиліття доклав значних зусиль для вирішення питання обов'язкової освіти для всіх дітей з обмеженими можливостями.

Прорезюмовані наукові праці надають підстави стверджувати про пріоритетність інклюзивної освіти в Китаї. Позитивним $\epsilon$ те, що державні школи та інші установи тісно співпрацюють, аби забезпечити постійні та стійкі можливості розвитку для освітян, які підтримують студентів-інвалідів та їхні сім’ї.

\section{Висновки}

Отже, незважаючи на всі заходи, що вживаються урядом Китаю, інклюзивна освіта все ще відстає в своєму розвитку від європейських країн, де діти з обмеженими можливостями $є$ повноцінними членами суспільства i не сприймаються оточуючими як «інші». Серед основних питань, пов'язаних з розвитком інклюзивної освіти в КНР, слід відзначити недостатню кількість професійних кадрів. Незважаючи на те, що особлива увага приділяється дослідженням даного питання і розробці планів реалізації розвитку інклюзивної освіти, існує і традиційний аспект сприйняття осіб з обмеженими можливостями. 3 огляду на необхідність організації інклюзивного навчання, яке $\epsilon$ пріоритетним, по всій країні створюються інститути інклюзивної освіти та ресурсні центри.

На основі проведеного аналізу наукової літератури, до основних передумов організації інклюзивної освіти в Китаї віднесено такі: включення всіх дітей з різними освітніми потребами до традиційних закладів загальної середньої освіти, які вони могли б відвідувати, якби у них не було інвалідності; відсутність «сортування» та відбору дітей, 
навчання в змішаних класах; розподіл дітей з фізичними i психічними особливостями по класах, відповідно до їхнього віку; ситуаційно обумовлена навальна взаємодія та координація ресурсів і методів навчання; використання децентралізованих моделей навчання.

Перспективи подальших розвідок вбачаємо у виокремленні особливостей організації інклюзивної освіти для дітей різного віку.

\section{Література}

1. Central Committee of the Communist Party of China. Outline of the National Plan for Medium and Long-Term Education Reform and Development (2010-2020). Beijing: Central Committee of the Communist Party of China. 2010.

2. Chen Y.Y. Making special education compulsory and inclusive in China. Cambridge Journal of Education. 1996. 26(1). 47-59.

3. Chen Y.Y. The research on effect evaluation of learning in the regular classroom of the disabled children. Chinese Journal of Special Education. 1997. 3. 45-48.

4. Deng M., Harris K. Meeting the needs of students with disabilities in general education in China. Teacher Education and Special Education. 2008. 1(3). 195-207.

5. Deng M., Poon-McBrayer K.F. Inclusive education in China: Conceptualization and realization. Asia Pacific Journal of Education. 2004. 24(2). 143-156.

6. Deng M., Zhu Z. The Chinese "learning in a regular classroom" and Western inclusive education: A comparison and exploration. Chinese Education and Society. 2007. 40(4). 21-32.

7. Hu X.Y., Wang M., Xiao F. Family quality of life of Chinese families of children with intellectual disabilities. Journal of Intellectual Disability Research. 2012. 56(1). 30-44.

8. McCabe H. The beginnings of inclusion in the People's Republic of China. Research and Practice for Persons with Severe Disabilities. 2003. 28(1). 16-22. 
9. Ministry of Education of the People's Republic of China. Special Education Improvement Act. Beijing. 2014.

10. Ministry of Education of the People's Republic of China. 2015 National Education Statistics. Beijing. 2016.

11. National Bureau of Statistics of China. Disability National Census. Beijing. 2007.

12. National People's Congress. Compulsory Education Law. Beijing. 1986.

13. National People's Congress. Compulsory Education Law. Beijing. 2006.

14. National People's Congress. Law on the Protection of Disabled Persons. Beijing. 2008.

15. Wang P., Michaels C.A. Chinese families of children with severe disabilities: Family needs and available support. Research and Practice for Persons With Severe Disabilities. 2010. 34(2). 21-32.

16. Wu S.L., Wang Y.L. Initiatives and practices of home schooling in inclusive education era. Journal of Modern Special Education. 2016. 7. 9-11.

\section{Цзен Гуанхай}

\section{Організація інклюзивної освіти В КНР}

\section{Анотація}

Стаття присвячена проблемі організації інклюзивної освіти в Китаї, шляхам опанування освітою здобувачами 3 особливими освітніми потребами, розвитку їхніх особистісних якостей, здатності до соціальної взаємодії, досягнення рівності в галузі освіти та соціальної справедливості. 3 моменту проголошення Саламанської декларації в 1994 р. багато країн світу, зокрема і Китай, рухаються до упровадження інклюзивної освіти. У статті розглядається історія та напрями організації інклюзивної освіти в Китаї. Автор вивчає досвід роботи вчителів при організації інклюзивної освіти, бар'єри та проблеми розвитку 
та впровадженні китайської інклюзивної освіти. Метою статті $є$ визначення основних передумов організації інклюзивної освіти в Китаї. Основними методами, які використовувалися в даному дослідженні, є аналіз і синтез наукової літератури й відкритих державних нормативноправових актів у галузі інклюзивної освіти в Китаї.

Автором встановлено, що незважаючи на всі заходи, що вживаються урядом Китаю, інклюзивна освіта все ще відстає в своєму розвитку від європейських країн, де діти 3 обмеженими можливостями $\epsilon$ повноцінними членами суспільства i не сприймаються оточуючими як «інші». Визначено, що особлива увага приділяється дослідженню інклюзивної освіти та розробці планів реалізації розвитку інклюзивної освіти. 3 огляду на необхідність організації інклюзивного навчання, яке є пріоритетним, по всій країні створюються інститути інклюзивної освіти та ресурсні центри. До основних передумов організації інклюзивної освіти в Китаї віднесено такі: включення всіх дітей з різними освітніми потребами до традиційних закладів загальної середньої освіти, які вони могли б відвідувати, якби у них не було інвалідності; відсутність «сортування» та відбору дітей, навчання в змішаних класах; розподіл дітей з фізичними i психічними особливостями по класах, відповідно до їхнього віку; ситуаційно обумовлена навальна взаємодія та координація ресурсів і методів навчання; використання децентралізованих моделей навчання.

Ключові слова: інклюзивна освіта, Китай, освітній процес, діти з особливими освітніми потребами, соціальна справедливість.

\section{Цзен Гуанхай}

\section{Организация инклюзивного образования в КНР}

\section{Аннотация}

Статья посвящена проблеме организации инклюзивного образования в Китае, путям освоения 
образования соискателями с особыми образовательными потребностями, развития их личностных качеств, способности к социальному взаимодействию, достижение равенства в области образования и социальной справедливости. С момента провозглашения Саламанской декларации в 1994 г. многие страны мира, в том числе Китай, движутся к внедрению инклюзивного образования. В статье рассматривается история и направления организации инклюзивного образования в Китае. Автор изучает опыт работы учителей при организации инклюзивного образования, барьеры, проблемы развития и внедрении китайской инклюзивного образования. Целью статьи является определение основных предпосылок организации инклюзивного образования в Китае. Основными методами, которые использовались в данном исследовании, является анализ и синтез научной литературы и открытых государственных нормативно-правовых актов в области инклюзивного образования в Китае.

Автором установлено, что несмотря на все меры, принимаемые правительством Китая, инклюзивное образование все еще отстает в своем развитии от европейских стран, где дети с ограниченными возможностями являются полноценными членами общества и не воспринимаются окружающими как «другие». Определено, что особое внимание уделяется исследованию инклюзивного образования и разработке планов реализации развития инклюзивного образования. Учитывая необходимость организации инклюзивного обучения, которое является приоритетным, по всей стране создаются институты инклюзивного образования и ресурсные центры. К основным предпосылкам организации инклюзивного образования в Китае отнесены следующие: включение всех детей с различными образовательными потребностями к традиционным заведениям общего среднего образования, которые они могли бы посещать, если бы у них не было 
инвалидности; отсутствие «сортировки» и отбора детей, обучение в смешанных классах; распределение детей с физическими и психическими особенностями по классам в соответствии с их возрастом; ситуационно обусловлена стремительное взаимодействие, координация ресурсов и методов обучения; использование децентрализованных моделей обучения.

Ключевые слова: инклюзивное образование, Китай, образовательный процесс, дети с особыми образовательными потребностями, социальная справедливость. 